\title{
Rubidium, Salami and Depression
}

\author{
You Cannot Have Everything in Life
}

\section{Caterina Canavese $^{a} \quad$ Ester DeCostanzi $^{b} \quad$ Daniela Bergamo $^{c} \quad$ Enrico Sabbioni $^{d}$ Piero Stratta ${ }^{a}$}

${ }^{a}$ Nephrology and Transplantation, Department of Nephro-Urology, Amedeo Avogadro University, Novara, ${ }^{b}$ Nephrology Unit, Department of Internal Medicine, Asti Hospital, Asti, cNephrology Section, University of Turin, and ${ }^{\mathrm{d}}$ European Commission, Joint Research Center, Ispra, Italy

\section{Key Words}

Malnutrition, quality of life • Depression • Rubidium • Dialysis

\begin{abstract}
Background: Depression may induce malnutrition, but, as a paradoxical hypothesis, malnutrition may induce depression. This relationship, of course, depends on how we define malnutrition. Current Knowledge: Rubidium is a trace element strongly linked with depression, and is deficient in uremia sufferers. However, in uremic patients, rubidium deficiency is more evident during predialysis, as it is at least partially corrected during dialysis and after transplantation. It seems that diet restrictions might be the main cause of rubidium deficiency, as it is mainly found in red meat. Conclusion: If rubidium is found in salami, then the occasional slice could be more beneficial for people suffering from depression than taking a lot of medication.
\end{abstract}

Copyright $\odot 2008$ S. Karger AG, Basel

\section{Background}

Depression is considered to be a typical neurobehavioral change in uremic patients [1-5], and nutritional intake has recently been linked to depression. Sufferers of depression tend to have bad diets [6]. However, we would like to turn this hypothesis on its head, and propose that whoever eats badly increases their likelihood of being depressed. Of course, in order to test these hypotheses, there needs to be a clear definition of what eating badly actually means. Unfortunately, at the moment, there is no common standard.

The trace element rubidium has several antidepressant properties. It belongs to the group of lithium, sodium, potassium and calcium, and it is exchangeable with potassium. It has rapid oral absorption, and slowly enters into the central nervous system (red blood cell:plasma ratio $=3: 20$ ). The total content in the human body is $400-$ $900 \mathrm{mg}$, with a weekly balance of 15-25 mg absorption and $20 \mathrm{mg}$ excretion, and its half-life is 30-60 days [7].

This is a rough outline of the history of rubidium as an antidepressant [8-17]:

- In 1891, the cardiologist Bottkin occasionally observed that cardiac patients treated with $\mathrm{RbCl}$ experienced increased well-being compared to patients treated with $\mathrm{KCl}$;

- In 1969, Dr. Meltzer discovered that the effects of rubidium in primates were the opposite of those produced by lithium;

- In 1976, the physiologist Mannistò observed that rubidium affects behavior in both animals and humans, as do amphetamines;

\section{KARGER \\ Fax +41613061234 \\ E-Mail karger@karger.ch}

www.karger.com
(C) 2008 S. Karger AG, Basel

0253-5068/08/0264-0311\$24.50/0

Accessible online at:

www.karger.com/bpu
Caterina Canavese

Nephrology and Transplantation, Department of Nephro-Urology

Amedeo Avogadro University, Novara, Ospedale Maggiore della Carità

Corso Mazzini 18, IT-28100 Novara (Italy)

Tel. +39 0321373 3798, Fax +39 0321373 3916, E-Mail ccanavese@hotmail.com 
- In 1984, the discovery was made that rubidium potentiates noradrenergic and dopaminergic transmission in the central nervous system by increasing the concentration of synaptic neurotransmitters;

- In 1994, rubidium-based drugs are used to treat serious depression with an efficacy as high as that obtained by tricyclic agents, but with fewer side effects. This was subsequently abandoned because of the appearance of new antidepressant drugs.

\section{Rubidium and Uremia}

The discussion concerning the role of rubidium as an antidepressant has recently been reopened because a deficiency has been discovered in uremic patients undergoing dialysis treatment [18-30]. Research is being carried out to discover if this deficiency is due to dialysis or a low rubidium intake in the diet. Results of initial studies suggest that the second case is more likely because the deficiency already begins in the predialysis phase $[20,22]$ when a low-protein diet is followed, and because the extent of the deficiency is inversely correlated to the duration of the dialysis, suggesting that beginning treatment leads to at least a partial correction of the defect [31-33]. What happens to the patients' diets when they begin treatment? They give up the low-protein diet and begin eating normally again, which means returning to a normal-protein diet, or even one including a high-protein intake.

Rubidium is mainly found in red meats [33, 34]. So, unsurprisingly, when we first compared the serum levels of rubidium in our dialysis patients with their eating habits, we noticed that those who ate salami, bresaola, sausages and cured meats on a fairly regularly basis had a higher level of rubidium [33]. This led us to conclude that if rubidium is mainly contained in red meats, and salami is made from red meat, then it must contain a high concentration of rubidium.

It was, of course, very amusing to think that we should advise our depressed patients with low rubidium levels to eat more salami. The obvious question that arises is: 'What about the lipids, cholesterol and triglycerides?' Quite simply, we had to smile and conclude that 'life is hard! You just can't have everything.' If you eat salami, your rubidium level increases and you no longer feel depressed, but you increase the risk of arteriosclerosis and the chances of dying early; if on the other hand you do not eat salami, you protect yourself from arteriosclerosis, but you could end up feeling more depressed or even sui- cidal! Of course, it would be very nice to have scientific evidence to confirm that salami is full of rubidium, providing a medically sound reason to eat it.

\section{The Brain's 2 Hemispheres}

The aims of the World Health Organization for the year 2000 were to add years to life and add life to the years. Every human being wants to live well, and for a long time.

Thanks to scientific discoveries, technological revolutions and the widespread availability of information, we have learned the importance of a healthy diet. Our cultural education has taught us to pick and choose those products which are good for us from the vast range available: those which contain vitamins, mineral salts and antioxidants, while avoiding foods which contain too many sugars or fats, especially the dangerous fats from animal meat that coat the walls of our blood vessels.

However, people have 2 cerebral hemispheres: the left side, which is inclined towards reasoning and the processing of structured and deductive projects, and the right side, which is more inclined towards artistic and emotive concerns, and responsible for those creative signals and impulses linked to pleasure and a sense of freedom. These 2 hemispheres are connected by bridges of organic tissue that allow for the continuous exchange of messages between the 2 parts, except in cases of severe pathological injury.

So, it naturally follows that when we are faced with appealing foods such as salami, chocolate, wine or pasta covered with a thick Bolognese sauce, we are overjoyed by the idea of eating or drinking all those things. Despite this, the left hemisphere does not give in, even though sorely tempted! It knows full well that to do so would jeopardize its dream of immortality and eternal youth. However, it can often find a way to justify erring from the strict rules that may make us eternally youthful, albeit joyless, unhappy and depressed.

Therefore, we find such wonderful and essential substances in normally forbidden foods, helping us to justify making an exception to the rule (even if these foods become more than just infrequent treats), e.g. chocolate contains endorphins [35-37], wine contains polyphenols [38-40] and, of course, salami contains rubidium. So, what exactly does this mean? Well, endorphins make you dream, polyphenols enlarge your coronary arteries and veins, and rubidium alleviates depression and puts a smile on your face [41]. What more could you ask for? Not 
even the more logical part of the brain and the outermost layer of the cortex can ignore this evidence.

The contributions that these potentially lethal foods (lethal because they contain lipids, alcohol and sugars) offer the body are fundamental for our quality of life, so they must be allowed in small doses every now and again. It is clearly not only better, but also more enjoyable, to occasionally have chocolate, salami and wine than to use medication to help overcome sleeping problems and mood disorders.

\section{Concluding Remarks}

Ever since the time of Adam and Eve, people have continuously looked for and found ways of using their brains to develop, and to justify the choices they make. Our highly developed cerebral cortex distinguishes us from our ancestors, and allows us to lead more fulfilling lives based on intelligent decisions. It enables us to see when 'we can break the rules' and enjoy ourselves. So, we should put this to use by discovering some of the beneficial properties in these 'forbidden foods', and a good place to start is measuring the rubidium content in salami!

\section{References}

1 Kutner NG, Fair PL, Kutner MIT: Assessing depression and anxiety in chronic dialysis patients. J Psychosom Res 1985;29:23-31.

2 Smith MD, Hong BA, Robson AM: Diagnosis of depression in patients with end-stage renal disease. Am J Med 1985;79:160-166.

-3 Craven JL, Rodin JM, Johnson L, Kennedy $\mathrm{SH}$ : The diagnosis of major depression in renal dialysis patients. Psychosom Med 1987; 49:482-492.

4 Kennedy SH, Craven JL, Roin GM: Major depression in renal dialysis patients: an open trial of antidepressant therapy. J Clin Psychiatry 1989;50:60-63.

5 Sacks CR, Peterson RA, Kimmel PL: Perception of illness and depression in chronic renal disease. Am J Kidney Dis 1990;15:3139.

6 Koo JR, Yoon JW, Kim SG, Lee YK, Oh KH, Kim GH, Kim HJ, Chae DW, Noh JW, Lee SK, Son BK: Association of depression with malnutrition in chronic hemodialysis patients. Am J Kidney Dis 2003;41:1037-1042.

7 Lombeck I, Kasperek K, Feinendegen LE, Bremer MI: Rubidium - a possible essential trace element. Biol Trace Elem Res 1980;2: 193-199.

-8 Meltzer HL, Taylor RM, Platmann SR, Fieve RR: Rubidium: a potential modifier of affect and behaviour. Nature 1969;223:321-322.

-9 Malek-Ahmadi P, Williams JA: Rubidium in psychiatry: research implications. Pharmacol Biochem Behav 1984;21(suppl 1):S49S50.

10 Williams RH, Maturen A, Sky-Peck HH: Pharmacologic role of rubidium in psychiatric research. Compr Ther 1987;13:46-54.

-11 Fieve RR, Meltzer HL, Dunner DL, Levitt M, Mendlewicz J, Thomas A: Rubidium: biochemical behavioural, and metabolic studies in humans. Am J Psychiatry 1973;130:5561.
12 Fieve RR, Meltzer HL, Taylor RM: Rubidium chloride ingestion by volunteer subjects: initial experience. Psychopharmacologia 1971; 20:307-314.

13 De Angelis L: Memory storage and effect of repeated treatment with a new antidepressant drug: rubidium chloride. J Int Med Res 1991;19:395-402.

14 Meltzer HL: A pharmacokinetic analysis of long-term administration of rubidium chloride. J Clin Pharmacol 1991;31:179-184.

15 Sopranzi N: Chronic administration of lithium and rubidium in rats: general behavior, explorative behavior and electric activity of the brain. Clin Ter 1993;142:211-218.

16 Torta R, Ala G, Borio R, Cicolin A, Costamagna S, Fiori L, Ravizza L: Rubidium chloride in the treatment of major depression. Minerva Psichiatr 1993;34:101-110.

17 Brundusino AO, Cairoli S: The pharmacological action of rubidium chloride in depression. Minerva Psichiatr 1996;37:45-49.

18 Sandstead HH: Trace elements in uremia and hemodialysis. Am J Clin Nutr 1980;33: 1501-1508.

19 Tsukamoto Y, Iwanami S, Marumo F: Disturbances of trace element concentrations in plasma of patients with chronic renal failure. Nephron 1980;26:174-179.

20 Smythe R, Alfrey AC, Craswell PW, Crouch CA, Ibels LS, Kubo H, Nunnelley LL, Rudolph H: Trace element abnormalities in chronic uremia. Ann Int Med 1982;96:302310.

21 Marumo F, Tsukamoto Y, Iwanami S, Kishimoto T, Yamagami S: Trace element concentrations in hair, fingernails and plasma of patients with chronic renal failure on hemodialysis and hemofiltration. Nephron 1984; 38:267-272.

22 Wallaeys B, Cornlesis R, Mees L, Lameire N: Trace elements in serum, packed cells and dialysate of CAPD patients. Kidney Int 1985; 30:599-604.
23 Allain P, Mauras Y, Tafforeau C, Houssin A, Cartier F: Changes in the plasma and erythrocyte concentrations of rubidium in patients with renal failure. Presse Med 1984;13: 2249-2251.

24 Van Renterghem D, Cornelis R, Vanholder $\mathrm{R}$ : Behaviour of 12 trace elements in serum of uremic patients on hemodiafiltration. J Trace Elem Electrolytes Health Dis 1992;6: 169-174.

25 Gallieni M, Brancaccio D, Cozzolino M, Sabbioni E: Trace elements in renal failure: are they clinically important? Nephrol Dial Transplant 1996;11:1232-1235.

26 Krachler M, Wirnsberger G, Irgolic KJ: Trace element status of hemodialyzed patients. Biol Trace Elem Res 1997;58:209-221.

27 Zima T, Tesar V, Mestek O, Nemecek K: Trace elements in end-stage renal disease: methodological aspects and the influence of water treatment and dialysis equipment. Blood Purif 1999;17:182-186.

28 Zima T, Tesar V, Mestek O, Nemecek K: Trace elements in end-stage renal disease. 2. Clinical implication of trace elements. Blood Purif 1999;17:187-198.

29 Krachler M, Scharfetter H, Wirnsberger GH: Exchange of alkali trace elements in hemodialysis patients: a comparison with $\mathrm{Na}(+)$ and K(+). Nephron 1999;83:226-236.

30 Krachler M, Wirnsberger GH: Long-term changes of plasma trace element concentrations in chronic hemodialysis patients. Blood Purif 2000;18:138-143.

31 Padovese P, Gallieni M, Brancaccio D, Pietra R, Fortunato S, Sabbioni E, Minoia C, Markakis $\mathrm{K}$, Berlin A: Trace elements in dialysis fluids and assessment of the exposure of patients on regular hemodialysis, hemofiltration and continuous ambulatory peritoneal dialysis. Nephron 1992;61:442-448. 
32 Sabbioni E, Pietra R, Serra MA, Fortaner S, Edel J, Minoia C: Application of nuclear, radiochemical and spectrochemical techniques in metal toxicology. J Trace Microprobe Tech 1993;11:217-229.

-33 Canavese C, DeCostanzi E, Branciforte L, Caropreso A, Nonnato A, Pietra R, Fortaner S, Jacono F, Angelini G, Gallieni M, Fop F, Sabbioni E: Rubidium deficiency in dialysis patients. J Nephrol 2001;14:169-175

34 Davie RJ: Rubidium; in Seiler HG, Sigel A, Sigel H (eds): Handbook on Metals in Clinical and Analytical Chemistry. New York, Marcel Dekker, 1994, pp 543-547.

>35 Benton D, Donohoe RT: The effects of nutrients on mood. Public Health Nutr 1999;2: 403-409.
36 Macdiarmid JI, Hetherington MM: Mood modulation by food: an exploration of affect and cravings in 'chocolate addicts'. Br J Clin Psychol 1995;34:129-138.

-37 Schuman M, Gitlin MJ, Fairbanks L: Sweets, chocolate, and atypical depressive traits. Nerv Ment Dis 1987;175:491-495.

>38 Martin S, Andriantsitohaina R: Cellular mechanism of vasculo-protection induced by polyphenols on the endothelium. Ann Cardiol Angeiol (Paris) 2002;51:304-315.
39 Pozo-Bayon MA, Hernandez MT, MartinAlvarez PJ, Polo MC: Study of low molecular weight phenolic compounds during the aging of sparkling wines manufactured with red and white grape varieties. J Agric Food Chem 2003;51:2089-2095.

$>40$ De Beer D, Joubert E, Gelderblom WC, Manley M: Antioxidant activity of South African red and white cultivar wines: free radical scavenging. J Agric Food Chem 2003;51: 902-909.

-41 Canavese C, DeCostanzi E, Branciforte L, Caropreso A, Nonnato A, Sabbioni E: Depression in dialysis patients: rubidium supplementation before other drugs and encouragement? Kidney Int 2001;60:12011202. 